\title{
Evaluation of Iron Tablet Program Among Pregnant
}

\section{Evaluasi Program Tablet Tambah Darah pada Ibu Hamil}

\author{
Assaini Carinta Padang, Haerawati Idris* \\ Department of Health Policy and Administration, Faculty of Public Health, \\ Sriwijaya University, Indralaya, Ogan Ilir 30662, South Sumatera \\ ("haera@fkm.unsri.ac.id)
}

\begin{abstract}
Anemia was one of the health problems throughout the world, especially in developing countries. The purpose of this study was to evaluate the program of iron tablets among pregnant women. This study used the CIPP evaluation model approach (Context, Input, Process, and Product). The Informant selected by the purposive method. The technique of data collection was done through in-depth interviews, document review, and observation. Data analysis was done by content analysis. The results of the study showed the components of the context of the birth of the blood supplement tablet program to reduce the prevalence of anemia in pregnant women. In the input, there was no division of tasks and responsibilities of human resources involved in the iron tablet program and the limitations of extension infrastructure. In the process, there were some health center officers who have not distributed iron tablets to pregnant women who have not made Antenatal Care visits. Some midwives did not provide reported to the Community Health Centers every month. This caused the majority of pregnant women were still not obedient to consuming iron tablets, and the results show that the target coverage has not been achieved.
\end{abstract}

Keywords : Evaluation, iron tablet, pregnant

\begin{abstract}
ABSTRAK
Anemia menjadi salah satu permasalahan kesehatan diseluruh dunia terutama negara berkembang. Dampak anemia pada ibu hamil dapat menyebabkan komplikasi saat kehamilan, sistem kekebalan tubuh menurun dan kematian pada ibu dan janin. Tujuan penelitian ini adalah mengevaluasi program pemberian tablet tambah darah pada ibu hamil. Studi ini menggunakan pendekatan model evaluasi CIPP (Context, Input, Process dan Product). Informan dipilih dengan metode purposive. Teknik pengumpulan data dilakukan dengan cara wawancara mendalam, telaah dokumen dan observasi. Analisis data dilakukan dengan menggunakan metode analisis isi. Hasil penelitian menunjukkan bahwa konteks lahirnya program pemberian tablet tambah darah untuk menurunkan prevalensi anemia pada ibu hamil. Hambatan pada lingkungan program yaitu ibu hamil berstatus pendidikan rendah dan belum sepenuhnya melakukan pemeriksaan kehamilan kebidan atau fasilitas kesehatan. Pada input, tidak terdapat pembagian tugas dan tanggungjawab SDM yang terlibat dalam program TTD, keterbatasan sarana prasarana penyuluhan. Pada proses adanya petugas puskesmas yang belum mendistribusikan tablet tambah darah pada ibu hamil yang tidak melakukan kunjungan ANC, serta beberapa bidan tidak memberikan laporan kepuskesmas setiap bulannya. Hal ini menyebabkan mayoritas ibu hamil masih belum patuh dalam mengkonsumsi TTD yang berdampak belum tercapainya cakupan sasaran.
\end{abstract}

Kata kunci : Evaluasi, tablet tambah darah, ibu hamil

Copyright (C) 2019 by author. This is an open access article under the CC BY-NC-SA license

(https://creativecommons.org/licenses/by-nc-sa/4.0/).

DOI : http://dx.doi.org/10.30597/mkmi.v15i4.7399 


\section{INTRODUCTION}

According to the World Health Organization (WHO) globally that the prevalence of anemia in pregnant women in the worldwide was $41.8 \%$. Anemia is common in developing countries and low socio-economic groups. The percentage of pregnant women from low-income families increases with increasing gestational age $(8 \%$ trimester anemia, $12 \%$ anemia in the second trimester and $29 \%$ anemia in the third trimester). ${ }^{1}$

Based on the results of Basic Health Research (RISKESDAS), the prevalence of anemia in pregnant women in Indonesia is 48, 9\%. This shows that the number exceeds severe public health problems with an anemia prevalence limit of more than $40 \%{ }^{2}$

Iron deficiency anemia in pregnant women is because of adherence and how to consume iron tablets not good so that there is a lack of iron absorption in the mother's body. The incidence of high iron-deficiency anemia harms pregnant women, such as increasing high morbidity and mortality, both mother and baby will be born. Therefore anemia requires serious attention from all parties involved in health services. ${ }^{3}$ Consumption of iron tablets very related to hemoglobin levels in pregnant women. Efforts are made to increase HB levels to avoid the occurrence of anemia in pregnant women, and the prevention of bleeding during childbirth. so pregnant women should be giving iron tablets of at least $90 \mathrm{Fe}$ tablets during pregnancy. ${ }^{4}$

The report of the City Health Office of Palembang city in 2016, the coverage of iron tablet for the city of Palembang was $92.72 \%$. The highest coverage for administering iron pills in Plaju Health Center was $97.99 \%$, and the lowest at Sei Selincah Public Health Center was 53.82\%. This coverage has not reached the national standard yet was $90 \%$, it is necessary to make efforts to achieve the targets set. ${ }^{5}$

Some study about evaluation of iron tablet among pregnant have done..$^{6-8}$ The results shows that some problem in effectiveness in distribution of iron tablet. Limited evidence study exists on an analytic and rational basis for programme decision-making, based on a cycle of planning, structuring, implementing and reviewing and revising decisions of this program. We try to used CIPP
Model to explore it. The purpose of this study was to evaluate the program of iron tablet among pregnant.

\section{MATERIAL AND METHOD}

This study used a qualitative research method which is arranged based on the framework that refers to Stufflebeam's theory, namely CIPP (Context, Input, Process, and Product). ${ }^{9}$ The collecting data obtain in-depth information, observation and document review. It can find problems clearly and can understand the meaning behind the data or information that appears, which in this case concerns the evaluation of the iron tablet program. ${ }^{10}$

The research informant consisted of one person from the Head of Nutrition Division at the City Health Office, one Head of the health centers, one pharmacist, and two urban village midwives. To select informant used the purposive technique. It considers that the informants know about this program. This research conducted at the Sei Selincah Health Center in Palembang City in May 2018. Data processing used qualitatively related to data reduction, data categorization, synthesis and working hypothesis. ${ }^{11}$ The data triangulation did the validity of the data. Triangulation was a technique of checking the validity of data that requires something other than data to check data or as a comparison to the data. ${ }^{12}$

\section{RESULTS}

The implementation for giving Adding Blood Booster Tablets was described in the form of an essay explanation using the CIPP evaluation model, which included context, input, process, and product. For Giving Blood Booster Tablets Program. Field findings on the context component were environmental support and program objectives. The environment was the factors that influence the iron tablet program in pregnant women in terms of social, cultural, and family support aspects. Socioeconomic factors, was the average majority of the population with low education status so that the lack of understanding iron tablets, cultural factors that affect the society not thoroughly carried out pregnancy checks to midwives or health facilities and family support that cannot cooperate with health workers and did not take Fe tablets or did not consuming Fe tablets. 
“... Yes, there must be, for example, from the socioeconomic conditions that pregnant women do not know whether the iron tablets, what the benefits, there are also cultural factors that they rarely check their pregnancy to the health center" (HR)

Based on the results of observations was conducted when research on environmental factors, was became an inhibitor of the iron tablet program was not optimal.

“... Yes, maybe from the knowledge of pregnant women who do not understand or do not know the purpose of consuming iron tablets, and some pregnant women are lazy to take drugs and are lazy to take their medicine" (SH)

Objectives were things that will be achieved in an implementation. Base on the background, the purpose of the establishment of a blood booster tablet program for pregnant women, was an effort to reduce the prevalence of anemia in pregnant women.

"... The aim of implementing the program is to increase their $H B$, because at the time of pregnancy, of course, they need for iron increases because the number of blood cells in pregnant women increases during pregnancy, second to increase the immune system, third to reduce the incidence of iron deficiency anemia in during pregnancy as well as the ultimate goal of reducing maternal and child mortality" (HR)

Based on a document review conducted by researchers on the latest RI Minister of Health Regulation No.88/2014 on standard Blood Add Tablets for women of childbearing age and pregnant women. To ensure that the whole process of blood tablet management starts from the receipt of goods to storage, distribution to targets, quality monitoring, and post-consumption management, quality management of blood-supplemented tablets is needed and a Guidebook is created for the Community Based Health and Nutrition Program by referring to the Guidance Book for the Management of Adding Blood Tablets released by the Ministry of Health in 2015 in an effort to reduce the prevalence of anemia in pregnant women (Table 1).

The findings in the field on the input component are the program implementation policies, infrastructure, human resources, and program funds. The strategy for implementing the program is a reference, guideline, and basis for the plan for implementing the iron tablet program for pregnant women. The system of this program refers to the 2015-2019 Strategic Plan to increase the coverage of family nutrition quality and awareness to improve community nutrition status, especially for pregnant women. In the implementation of the program and distribution coverage refers to the Ministry of Health's circular letter related to the program and the Minister of Health Regulation No. 88 of 2014 on iron tablets for pregnant women and the policy made by the government that one of them is distributing Fe tablets through the TTD is given by midwives when ANC visits.

"... The policy of this program refers to the Strategic Plan in terms of increasing the coverage of the nutritional quality of pregnant women and law in Permenkes 882014 concerning stand- ard administration of blood tablets for this program policy, pregnant women, get a TTD for nine months of pregnancy or at least 90 pills" (HR)

Resources are precious assets to achieve a goal. The quantity of iron tablet program officers in this pregnant woman was three people, one mid-

Table 1. Summary of the Qualitative Research Results on the Context Components in the Blood Booster Tablets Program in Pregnant Women

\begin{tabular}{lll}
\hline Variable & \multicolumn{1}{c}{ Research Results } \\
\hline Environmental barriers & $\begin{array}{l}\text { 1. } \\
\text { 2. }\end{array}$ & $\begin{array}{l}\text { The majority of the average population is in the best status of education } \\
\text { had their pregnancies checked regularly and there are pregnant women who } \\
\text { deliberately do not take tablets plus blood or do not take blood-added pills }\end{array}$ \\
3. & Objectives Efforts to reduce the prevalence of anemia in pregnant women. \\
\hline
\end{tabular}


Table 2. Summary of Qualitative Research Results on the Input Components of the Iron Tablet Program for Pregnant Women

\begin{tabular}{|c|c|}
\hline Variable & Research Results \\
\hline Policies & $\begin{array}{l}\text { 1. Strategic Plan (Strategic Plan) } 2015-2019 \text { to increase the coverage of } \\
\text { quality and awareness of family nutrition } \\
\text { 2. The latest Regulation of the Minister of Health of the Republic of } \\
\text { Indonesia No.88/2014 concerning the standard of Blood booster Add } \\
\text { Tablet for women of childbearing age and pregnant women }\end{array}$ \\
\hline Human resources & $\begin{array}{l}\text { 1. The number of human resources in the program of giving iron } \\
\text { tablets three people are } 1 \text { KIA officer and two village midwives who } \\
\text { concurrently distribute blood tablets to pregnant women. } \\
\text { 2. Educational background for Midwifery Diploma III }\end{array}$ \\
\hline Advice and infrastructure & $\begin{array}{l}\text { 1. Availability iron tablets. } \\
\text { 2. The facilities for promotion such as leaflets, booklets, and posters } \\
\text { were lack. }\end{array}$ \\
\hline Funding sources & $\begin{array}{l}\text { 1. Funds for the iron tablet program are sourced from the state budget } \\
\text { (APBN), regional budget (APBD), and logistics funds. } \\
\text { 2. Transport funds for program officers come from BOK. }\end{array}$ \\
\hline
\end{tabular}

wife coordinator (KIA) and 2 Village Midwives.

“... Those involved in this program were clear that the head of the health center deck in, if the health center responsible for this program was the head of health centers, and was assisted by nutrition officers and KIA midwives, with other midwives also" (AY)

For the human resources available in the iron tablet supplementation program, there is no standard for determining the number, qualifications of health workers, and the distribution of duties/responsibilities of health workers involved.

"... If the first person in charge of this program was helped by nutrition officers and other midwives who helped prescribe tablets to pregnant women because all the staff worked together on desk from nutritionists, KIA, pharmacy officers, midwives, and midwives" (SH)

The facilities and infrastructure contained in this program are only a few, from the statement of the informants of the facilities and support provided in the program to add blood tablets.

“... The facilities and infrastructure for this iron tablet supplement program are only in the form of tools for promotion and counsel- ing in the form of leaflets only, the availability of blood-added tablets and also maternal and child health books" (AY)

The observation results through the observation sheet that the researchers only found iron tablets, $\mathrm{MCH}$ books and maternal health records as recording and reporting, and promotional facilities only used leaflets, and not seen booklets and posters in this program. So it can be concluded that the facilities and infrastructure in this program still lack or not optimal because there are still limited educational infrastructure facilities.

Funds are resources needed to support the implementation of a program. The source of funds for the blood tablet supplement program for pregnant women came from APBD funds, APBN, and logistical funds, but in this program, there were no funds in the primary health care because they only received added blood tablets which were given by the Health Office pharmacists but for the public health center staff. Get transport funds from BOK funds.

“... For sources of funding for iron tablet programs for pregnant women, they come from the state budget, regional budget, and logistics funds" (HR) 
The source of funding for this program must come from the National Budget (APBN), Regional Budget (APBD), and BOK funds for blood tablet supplement programs for pregnant women in the form of counseling, promotion, implementation of a blood tablet supplement program for pregnant women (Table 2).

Variables in the component process are planning, provisioning, distribution and recording, and reporting. Planning for iron tablets is conducted pharmacists by making a worksheet on the preparation of drug procurement. This drug procurement planning worksheet consists of names of drugs, packaging, price, packaging, remaining stock, total packaging usage, and total proposed needs and overall costs. The planning process that is carried out is to determine the target number of pregnant women, by making a recapitulation of urban village data which is then agreed upon by the $\mathrm{MCH}$ and nutrition fields and the real target data used to submit requests for iron tablets to the health office.

“... Planning for the needs of iron tablets at the health center level is carried out by pharmacy officers and starts from arranged since the end year together with other types of supplements or drugs" (HR)

The component of the process of supplying iron tablets needs to be carefully calculated because it will affect the supply process. In the supply process, among them are the targets, pregnant women whose numbers are known precisely to prevent the occurrence of deficiencies or vice versa the excess amount of Fe tablets provided.

“... Yes, the availability of tablets plus blood booster that we receive is following the goals of the plan that we submitted" (RN)

The process of supplying blood tablets is carried out based on the results of the Usage Report and Drug Request Sheet (LPLPO) from the health center to the Health Service every month, and a pharmaceutical warehouse is obtained.

"... It is done from the pharmacy office of the warehouse through a report on the demand and use of the drug or LPLPO" (SH)
The process of implementing the distribution is to propose the need for tablets with blood from the number of targets that have been determined to the Health Office. After getting an additional blood tablet from the Health Officer, the health center distributes iron tablets to pregnant women in the health center working area according to the target number of pregnant women in each regional.

"... The process of distribution from the Health Office entered the health center through pharmacy and for this we have already prepared nutrition workers in the Sei Selincah Community Health Center in co-operating with the MCH and other Midwives fields and will be distributed to pregnant women" $(D N)$

The process of distributing blood-added tablets and counseling and outreach was carried out by the $\mathrm{MCH}$, nutrition staff, and other midwives in the primary health care during the class of pregnant women.

“... Yes, we also conducted counseling and screening of pregnant women during the class of pregnant women, namely about the benefits of consuming iron tablets and the drinking rules that were carried out by program managers assisted by nutrition officers at the health center" (AY)

Recording and reporting on the distribution of added blood tablets are carried out by midwives in the village where records are included in the register of pregnant women. In the book, there are listed for the provision of $\mathrm{Fe} 1, \mathrm{Fe} 2$ and $\mathrm{Fe} 3$ so that the midwife has to mark the column on the $\mathrm{Fe}$ tablet, which is what the expectant mother gets.

“... Reported every month. The report, it could also be the first midwifery, KIA in to nutritious. We have it too. It's just more powerful here. Because if we are in our place, we use the Posyandu report, but it is not very detailed. If they are here, they will report" (DN)

There is no format for reporting accurately for tablets from the nutrition coordinator for midwives in the village because what is used is the reporting format of the village midwife provided 
Table 3. Observation Results on Iron Tablet Supplementation Programs for Pregnant Women

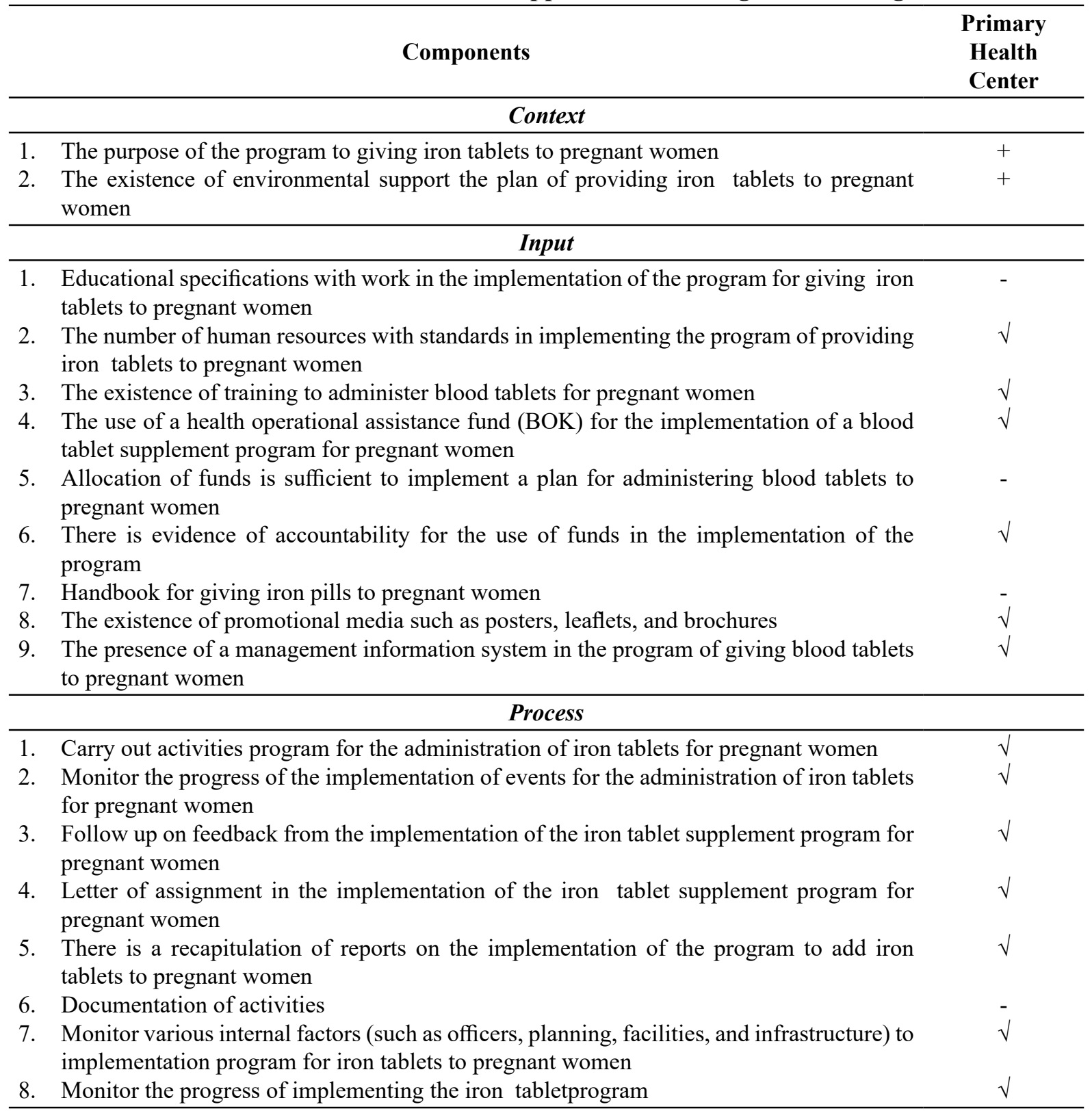

\section{Product}

1. Data socialization program for giving iron tablets to pregnant women -

2. Specific data for anemia affected

3. Data on the target program for giving iron pills to pregnant women

4. Data on the implementation achieve of the application for administering iron tablets to pregnant women

by the KIA coordinator and the report goes to the KIA section. This report from the midwife to the KIA coordinator was then asked by the nutrition coordinator to be recapitulated (Table 3).

"...Every month the village midwife reports to us. If the select format is from the KIA re- cap, there should also be nutrition for each village. So the town says to KIA"'(SH)

Variables in product components are target units and distribution coverage. Target complian- 
ce is the goal of following orders and recommendations for consuming iron tablets following applicable rules. To see the observance of targets in consuming pills can be seen by monitoring the health records of pregnant women and looking at reports on the achievement of maternal and child health programs and a register of cohorts of pregnant women.

“... Yes, to find out the compliance of our goals in consuming tablets, yes, pregnant women have KIA books and are taken during ANC visits. There we can see them routinely, or they don't come to check and how many times have they been taken. And also know The cohort register of pregnant women village" (SR)

The researchers conducted cross-checks on pregnant women in each town, whether it was following what the nutrition officer said about the compliance of the target. From the eight pregnant women who were taken from each community as their representatives, they got results, taking iron tablets according to what was explained by the midwife, but sometimes some pregnant women received added blood tablets but did not take TTD.

“... I drank the deck but not routinely sometimes forget about it" (YT)

The distribution coverage of the iron tablet program for pregnant women follows the $95 \%$ achievement target of the Indonesian Ministry of Health to improve the next program so that existing applications can run better. The goals in the iron tablets are pregnant women who only visit ANC, do not include pregnant women who do not visit ANC because they will find it difficult to determine the real data coverage of the tablet supplement target.

“... For the coverage of the TTD distribution, we follow the regulation of the Ministry of Health of $95 \%$ for the year 2018 pregnant mothers get TTD, but for our goals, we have recorded all the health centers in Palembang, and we distribute them to all health centers. If from a health center, if from a health center there is of course" (HR)

The results of distribution coverage still have not reached the target if accumulated in one year because the distribution coverage is calculated at the end of the year. The constraints experienced are giving of TTD still not reaching the target in remote areas, pregnant women who do not routinely conduct ANC visits, TTD is also prioritized for pregnant women who regularly conduct ANC visits.

"... If the coverage for 2018 is still uncertain because it has not yet been accumulat$\mathrm{ed}$, indeed yesterday it was related to the TTD program in 2016 we were very low, but after evaluation in 2017, it was much improved because we immediately went down to spread the TTD on pregnant women" $(D N)$

\section{DISCUSSION}

The purpose of this study was to evaluate the program of iron tablet among pregnant women. This study used the CIPP evaluation model approach (Context, Input, Process, and Product). We found that in the context, the purpose of this program is to reduce the prevalence of anemia in pregnant women, increase the immune system, increase HB levels so that it can avoid anemia in pregnant mother and prevent bleeding during childbirth. Pregnant women are given at least 90 tablets of iron tablets during pregnancy, and to reduce maternal and child mortality. ${ }^{12}$ Based on a review of the latest RI Minister of Health Regulation document No. 88/2014 about standard Blood Booster Tablets for women of childbearing age and pregnant mother. To manage it, starts from the receipt of goods to storage, distribution to targets, quality monitoring, and post-consumption management, quality management of iron tablets is needed, and a Guidebook is created for the Community Based Health and Nutrition Program (PKGBM) working area. ${ }^{13}$ Quality programs will not succeed when implemented in environmental conditions and conditions that are not conducive to achieving goals such as geographic, social, economic, political, and cultural-ecological factors. ${ }^{14}$ Cultural factors have a profound and profound influence on consumer purchasing behavior in these cultural factors. Several components include cultural factors as the most fundamental determinant in terms of one's desires and behavior because culture concerns all aspects of human life. ${ }^{15}$ Environ- 
mental factors in implementing the program are also a determining factor. Several factors influence the compliance of pregnant women, including the behavior of health workers, where compliance can be further improved if the village midwife can provide nutrition counseling, especially about the benefits of iron tablets and the health of pregnant women.

The policy is a decision in the form of guidelines for acting both simple and complex, both general and specific, which are formulated through a political process for a particular course of action, programs, and plans in carrying out health services. ${ }^{16}$ In the implementation of programs and distribution coverage refers to circulars Ministry of Health-related to the program and Minister of Health Regulation No. 88 of 2014 for iron tablets for pregnant women with the aim of ensuring the availability of quality and standardized TTD in order to prevent and overcome iron nutrition anemia in women of childbearing age with priority for pregnant mother. ${ }^{17}$ The policy is an assessment of value systems and situational needs factors, which are operated in an institution as general planning. The goal is as a guide in making decisions so that the desired goals can be achieved. A policy is said to be successful if the system implemented has the desired impact. Facilities and infrastructure are closely related to the physical appearance of health facilities, comfort, cleanliness, tidiness, completeness of inspection equipment, and the variety of drugs provided are factors to attract the community to obtain health services. ${ }^{18}$

In input, stages in achieving the availability of health personnel resources starting from planning, education and training stages and energy utilization at the scene of health services. ${ }^{19}$ Compared with the provision of supplementary tablets, types and numbers of health workers analyzing workloads, taking into account the number of services held, the population and distribution, characteristics of the work area, working area, availability of other first-rate health care facilities in the work area, and division of labor time division of labor have been carried out based on educational background and capabilities of the officers in the health center but there are no specific criteria and more precise. The successful development of community participation in the implementation of the iron tablet supplement program for pregnant women is related to the availability of health workers and facilities used..$^{20}$ According to research, the role of health workers in motivating pregnant women to consume iron tablets is a good majority, 12 whereas according to study Aaron Wildavsky said that the part of health workers is related to compliance with consumption of Fe tablets. Operational funds for the successful distribution of Fe tablets, there is a statistical relationship between the ratio of sufficient funds and insufficient to the added iron tablet coverage. It means that health centers that have sufficient operational funds have five times greater opportunities to reach the $80 \%$ distribution target. $^{21}$

Inprocess, planningisone of the vitalmanagement functions, which is considered as the locomotive of an activity, without planning the objectives to be achieved will not work well. ${ }^{20}$ Planning for the need for iron tablets is carried out by pharmacists following Minister of Health Regulation No. 88 of 2014 concerning the standard of giving iron pill is calculating targets and calculating needs within one year based on the number of goals. ${ }^{21}$ This study is in line with research into the program, the administration of iron tablets that planning drug needs is the main activity before all drug management processes. Efforts to provide additional blood tablets to be available and accepted by all pregnant women in the Sei Selincah Community Health Center work area, in the process of providing there are no obstacles and the availability of iron tablets is following the intended goals. The distribution process is going every week to be the reason that the existing Fe tablet stock is kept in the health center, the process of distributing the blood tablet itself is done by the health center midwife in accordance with the Technical Guidelines (iron) in the implementation of the iron tablet supplementation program, but the distribution process only in health center, even though according to technical guidelines the distribution process can be done at the posyandu level, and some health facilities are under the working area of the primary health care. As for the constraints in giving blood tablets to pregnant women, namely, pregnant women who do not routinely take pills are more bloody. Another obstacle is that pregnant women do not regularly conduct examinations and do not 
make ANC visits. The recording and reporting is an essential part of monitoring and evaluation activities. Recording of monthly reports is collected in the cohort of pregnant women book owned by the health center. Besides, pregnant women will also get a record of the administration of iron tablets listed in their control books. ${ }^{22,26}$ The forms of reporting owned by health workers are following the existing implementation standards but seen from the completeness of the documents it turns out that this health worker has complete records throughout 2018 with negligent reasons for storing these documents.

In output, target compliance is the goal of following orders and recommendations for consuming iron tablets following applicable rules. Based on the Minister of Health Regulation No. 88 of 2014, one indicator of the success of the iron tablet supplement program in pregnant women is adherence to goals. From the results of the research program, the administration of iron tablets is still a lack of adherence to the target in consuming TTD so that it always cannot be said to be successful. The results of research conducted by Fitrayeni, Suryati, and Rizki Mela Faranti that there is a relationship between adherence to the consumption of Fe tablets with the incidence of anemia. Pregnant women need to consume Fe tablets during pregnancy because the iron needs of pregnant women increase during pregnancy. ${ }^{23}$

The involvement of posyandu cadres in the accompaniment of drink iron tablet in pregnant women can improve maternal compliance in taking blood added drugs so as to increase hemoglobin level and decrease the incidence of anemia. ${ }^{24}$ The impact of anemia on the mother can occur during pregnancy, during labor, or childbirth. Obstacles that affect adherence to the goal of consuming iron tablets are that the occurrence of black discoloration in feces, nausea, and unpleasant odor of the drug. How to deal with and how to deal with complaints due to side effects of $\mathrm{Fe}$ tablets so that the nutritional needs of the mother and fetus can be fulfilled. ${ }^{23}$ Research conducted by Rimawati et al. mentioned that the lack of Fe not only is fulled from consuming food source $\mathrm{Fe}$ or giving but it is essentially giving accelerate (enhancer) absorption of $\mathrm{Fe}$ and reduces food consumption which inhibits (inhibits) absorption of Fe. Physiological changes in the body of pregnant women, breastfeeding mothers increase Fe's need for the body, the types of food eaten, which can affect Fe bioavailability in the body. ${ }^{25}$

In product, we found that the results of coverage available on the iron tablet supplement program for pregnant women, which is the achievement target and to improve the next program so that the existing applications can run better. According to the regulation of the Minister of Health of the Republic of Indonesia, coverage of TTD distribution and consumption for pregnant women at the national level in 2014 , at least $85 \%$ of pregnant women received TTD. ${ }^{14}$ Whereas the results of the TTD distribution coverage in the working area of Sei Selincah Primary Health Center still have not reached the target if accumulated in one year because the distribution coverage is calculated at the end of the year. The constraints experienced are, in the form of TTD still not reaching the target in remote areas, pregnant women who do not routinely conduct ANC visits, TTD is also prioritized for pregnant women who regularly attend $\mathrm{ANC}$ visits.

\section{CONCLUSIONS}

The program of giving iron tablets is still not optimal. The evaluation results in the context component are the program objectives to reduce the prevalence of anemia in pregnant women and reduce mortality in mothers and children. Obstacles in the environment are socioeconomic factors where pregnant women have a low education status, cultural factors where mothers still do not fully carry out pregnancy checks to midwives or health facilities. The results of the evaluation of the input component are that there is no division of duties and responsibilities of human resources involved in the program to provide iron tablets and the limitations of extension infrastructure.

Completing procurement records and planning of iron tablets and distributing iron tablets throughout the health centers covered by the Palembang Health Office. Coordinated and distribute blood tablets to pregnant women who do not have ANC visits. Midwives provide counseling to pregnant women during ANC examinations or classes for pregnant women and provide information to their families about the importance of 
taking Fe tablets for pregnant women.

\section{REFERENCES}

1. WHO. Guideline: Daily Iron and Folic Acid Supplementation in Pregnant Women. Geneva; 2015.

2. Kemeneterian Kesehatan RI. Laporan Nasional Tahun 2013: Riset Kesehatan Dasar. Jakarta: Badan Penelitian dan Pengembangan Kesehatan Kementerian Kesehatan Republik Indonesia; 2018.

3. Manuaba IB, Manuaba IC, Manuaba IB. Pengantar kuliah obstetri. Jakarta: EGC; 2007.

4. Dewantoro NK, Muniroh L. Studi Deskriptif Program Suplementasi Tablet Besi pada Ibu Hamil di Puskesmas Kalijudan Kota Surabaya. Amerta Nutrition. 2017;1(4):308-317.

5. Dinas Kesehatan Kota Palembang. Profil Kesehatan Kota Palembang. Palembang: Dinas Kesehatan Kota Palembang; 2017.

6. Shanti KM, Maitri AK, Rosselo J, Destriyani D, Friday LC, Novriana R. Evaluasi Program Pemberian Tablet Tambah Darah (TTD) Sebagai Upaya Preventif dan Kuratif Anemia Ibu Hamil di Puskesmas Kraton Kota Yogyakarta. Berita Kedokteran Masyarakat. 2017: 33(5).

7. Purwati P, Tamtomo D, Sulaeman ES. Context, Input, Process, Product Analysis in the Implementation of Iron Supplementation Program in Banyumas, Central Java. Journal of Health Policy and Management. 2016;1(2):120-127.

8. Septiani W. Pelaksanaan Program Pemberian Tablet Zat Besi $(\mathrm{Fe})$ pada Ibu Hamil di Wilayah Kerja Puskesmas Tambang Tahun 2016. Journal of Midwifery Science. 2017;1(2):86-92

9. Widoyoko SE. Evaluasi Program Pembelajaran: Panduan Praktis Bagi Pendidik dan Calon Pendidik. Yogyakarta: Pustaka Pelajar; 2013.

10. Saryono A. Metodologi Penelitian Kualitatif dan Kuantitatifdalam Bidang Kesehatan. Yogyakarta: Nuha Medika. 2013.

11. Arikunto S, Jabar CS. Evaluasi Program Pendidikan. Jakarta: Bumi Aksara; 2004.

12. Muninjaya, A.A. Gde. Manajemen Kesehatan. Jakarta: Buku Kedokteran. EGC; 2004.
13. Fajar S, Heru T. Manajemen Sumber Daya Manusia. Yogyakarta: UPP STIM YKPN. Yogyakarta; 2013.

14. Peraturan Menteri Kesehatan RI Nomor 88 Tahun 2014 Tentang Standar Tablet Tambah Darah Bagi Wanita Usia Subur dan Ibu Hamil. Jakarta: Kementerian Kesehatan RI; 2014.

15. Purwanto \& Sulistyastuti. Implementasi Kebijakan Publik. Yogyakarta: Penerbit Gava Media; 2012.

16. Adisasmito, W. Sistem Kesehatan. Jakarta: PT. Raja Grafindo Persada; 2007.

17. Bustami. Penjaminan Mutu Pelayanan Kesehatan \& Akseptabilitasnya. Jakarta: Erlangga; 2011.

18. Winarno. Kebijakan Publik, Teori, Proses, dan Studi Kasus edisi \& Revisi Terbaru. Yogyakarta: Center for Academic Publishing Service; 2012.

19. Kementerian Kesehatan RI. Pedoman Pelaksanaan Program Jaminan Kesehatan Nasional. Jakarta: Kementerian Kesehatan; 2014.

20. Manuaba, Ilmu Kebidanan Penyakit Kandungan dan Keluarga Berencana untuk Kebidanan. Jakarta: EGC; 2010.

21. Wildavsky A. Doing Better and Feeling Worse: the Political Pathology of Health Policy. Daedalus. 1977:106(1); 105-123.

22. Lubis AS. Analisis Manajemen Logistik Obat di Instalasi Farmasi Dinas Kesehatan Kabupaten Deli Serdang Lubuk Pakam Tahun 2017. [Skripsi]. Medan: Universitas Sumatera Utara; 2017.

23. Fitrayeni, Suryati, Faranti RM. Penyebab Rendahnya Kelengkapan Kunjungan Antenatal Care Ibu Hamil di Wilayah Kerja Puskesmas Pegambiran. Jurnal Kesehatan Masyarakat Andalas. 2017;10(1):101-107.

24. Wahyuni S. Efektifitas Pendampingan Minum Tablet Tambah Darah (TTD) oleh Kader Posyandu terhadap Peningkatan Kadar $\mathrm{Hb}$ Ibu Hamil di Puskesmas Kota Palangka Raya. Jurnal Surya Medika (JSM). 2018;3(2):82-94.

25. Rimawati, E., Kusumawati, E., Gamelia, E., Sumarah, \& Nugraheni, S. A. Intervensi Suplemen Makanan untuk Meningkatkan Kadar Hemoglobin pada Ibu Hamil. Jurnal Ilmu Kesehatan Masyarakat. 2018;9(3):161-170. 